\title{
The return of the muro: Institutional bricolage, customary institutions, and protection of the commons in Lembata Island, Nusa Tenggara
}

\author{
Nurhady Sirimorok ${ }^{1,}{ }^{*}$ and Asfriyanto Asfriyanto ${ }^{1}$ \\ 1 Peasant School Network of PAYO-PAYO. Maros, South Sulawesi, Indonesia. \\ * Corresponding author: nurhadys@gmail.com
}

\begin{abstract}
The Lembata region is known for complex environmental conflicts between local institutions and external interests to protect endangered species such as the dugong and sperm whale. In this paper, we examine how the Tokajaeng community applies traditional rules (muro) in the face of environmental threats to the commons, such as depletion of forests and mangroves, and degradation of coral reefs. Critical Institutional Analysis is applied to examine institutional arrangements governing the commons. The approach acknowledges the complexity of institutions entwined in everyday social life, power relations that animate them, their socio-historical formation, and interplay between formal and informal institutions, as well as the convergence between modern and traditional arrangements. Fieldwork involved in-depth investigation on how the Tokajaengs create and applied rules (muro) and how they actively participated in the process of establishing new rules. We find that the muro responds reflexively to both internal and external dynamics in protecting the commons. They at once adapt to changes that threaten the commons in a way that each new threat corresponds with a new rule. Therefore, although the muro is a longstanding institution for local conservation, once suppressed for almost three decades during the New Order era, new arrangements have emerged since 2005 following political reforms in Indonesia. In the context of state efforts applying top-down conservation instruments, the muro shows the value of local institutional authority rooted in local belief systems that can take on new shapes through adaptive mechanisms. The muro therefore offers new opportunities for rethinking conservation in the Wallacea region, in ways that can actively engage local authority to devise and enforce rules to protect the environment.
\end{abstract}

Keywords: institutional arrangement; commons; customary institution; conservation; muro; Lembata; Tokajaeng

\section{Introduction}

Debates on the importance of institutions for managing and protecting common-pool resources (CPR) began in response to Garrett Hardin's prognosis that virtually all commons will end in a so-called tragedy of the commons (Hardin 1968). To avoid such an outcome, the postulate recommended that all commons be protected either through policies of privatization or strong centralized intervention by the state. Among the most persistent critiques of Hardin's rational choice view is Ostrom's (1990) more nuanced institutionalist critique. She argues that Hardin's version of the commons is limited by its fictitious example, indeed a metaphor that Ostrom empirically and systematically debunks. Her studies further show that most commons are collectively managed CPRs, which have clear boundaries and participant/managers who develop institutional arrangements to ensure shared benefits and conservation outcomes. This institutionalism critique of the rational choice perspective understands the commons as something to be managed by diverse collective participants to achieve joint benefits, one which have mechanisms for establishing new rules.

However, the institutionalism critique also lacks the consideration of local norms, values and interests. Ostrom's particular 'institutional mixtures' governing the commons ${ }^{1}$ also requires further

\footnotetext{
${ }^{1}$ Drawing on studies from different parts of the world, Elinor Ostrom (1990) identified eight 'design principles' developed by local people to govern their CPR, and thereby ensure the success of managing the commons. They are as
} 
attention to multi-scalar systems (whether geographically, institutionally, and historically), in which the commons always played an integral part of societal framings. Furthermore, commons are also subject to political struggles among internal groups, as well as among different institutions that govern the commons at different levels (Saunders 2014; Cleaver and de Koening, 2015). One of the aims of studying the commons is to find out ways in which CPR ecosystem services ${ }^{2}$ can be maintained by a group of users/proprietors, either by preventing overuse or underuse (Miyagana and Shimamada 2018).

This study extends the research on the commons by supporting empirical engagement on understanding historical and cultural dimensions. We do so by adopting a 'critical institutionalism' approach which is a body of thought that explores how institutions negotiate relations among resources, people and wider society. The approach acknowledges the complexity of institutions entwined in everyday social life, the power relations that animate them, their socio-historical formation, and interplay between formal and informal institutions, as well as the convergence between modern and traditional arrangements. Furthermore, our research site (Lembata Island, District of Lembata, Nusa Tenggara) is also geographically situated in an under-researched region, engaging on elements of both coastal and terrestrial resource institutions among small island regions of Wallacea. Forests and fisheries such as the ones managed by the Tokajaeng as their customary area are examples of the commons that provide economic, ecological, social, and cultural benefits to the people in this region. As in other places, the common resources within Tokajaeng customary areas also require the community to develop traditional institutions and organizations of to manage the CPRs. The tradition of CPR management of the Tokajaeng includes making and enforcing rules called muro. ${ }^{3}$ The muro is an umbrella term, which includes a different set of rules formulated through public meetings and rituals, and defines prohibited and acceptable practices to protect certain areas and species.

This paper focuses on examining the roles of muro and its dynamics in protecting CPRs, which also functions as habitats for endangered species. This research asks: How do the Tokajaengs create and apply rules (muro) and how do they actively participate in the process of establishing new rules? How does the community respond to both internal and external threats to natural resources? What are the resulting mechanisms and the ways in which communities apply and follow such rules? Such an exposition provides better context for engaging on questions of community conservation in the region. We identified two different types of threats to resource management in Lembata. As we will show, on the one hand, some of these threats are internal, where community members themselves have negatively influenced the use of a resource. On the other hand, threats to the environment can come from external factors, particularly with the expanded influence of state policies and commoditization of resources. Our research shows that there are dynamic processes and innovative instruments that the communities use in response to these environmental threats. This paper will describe how village institutions responded to these threats by creating new adaptive rules.

The paper proceeds as follows. In the next section we briefly describe our theoretical framework which engages with institutional perspectives of the commons. In particular, we extend institutional perspectives by more closely examining local traditional rules that allow access and regulate the use of natural resources. We also situate the research to examine the Wallacea region as an island with both marine and terrestrial conservation considerations. The third section lays out our research methodology, followed by an overview of the case study location. We thereafter

follows: 1) clearly defined geographical and social boundaries, 2) congruence between rules and available resources, 3) participation in rulemaking, 4) effective monitoring, 5) graduated sanctions, 6) affordable conflict resolution mechanisms, 7) minimal recognition of rights to organize, 8) nested enterprises. (p. 90).

2 Ecosystem services here refer to "the direct and indirect contributions of ecosystems to human well-being" (ibid.: 335).

${ }^{3}$ For more detailed discussions on the rule making, enforcement and compliance of the commons, see Epstein (2017). 
present our findings, structured as three different cases relating to the application of the muro. Lastly, we discuss the conceptual and policy implications of the study before making conclusions.

\section{Theoretical Framework}

This study adopts a 'critical institutionalism' approach, which delves into the way institutions dynamically regulate interactions between people, natural resources, and society (Cleaver and De Koening, 2015). The approach acknowledges the complexity of institutions governing the commons: that they have distinct socio-historical formations, entwined in everyday social life, hence may contain interplay between formal and informal institutions, converges between modern and traditional arrangements, and they are animated amidst certain power relations. Critical institutionalism is particularly favorable because it can capture the complexity of the institutions governing the commons, in this case the ulayat (customary area comprised of land, coasts, and sea). It can direct us to see how such traditional commons can be managed for sustainable use while interacting with different types of norms, rules, and organizations; and how the local institutions themselves can be (re)shaped into different institutional arrangements while enduring multiple changes that affected them.

An important concept that can capture both the interactions of different institutions and historical processes governing the commons is "institutional bricolage." Institutional bricolage here is understood as "a process through which people, consciously and non-consciously, assemble or reshape institutional arrangements, drawing on whatever materials and resources are available, regardless of their original purpose" (Cleaver and De Koening, 2015: 4). Within this continuous process, institutional arrangements undergo modifications, by receiving additional internal innovations and the adoption of various institutional components from elsewhere. Older arrangements are replaced, reused, or refashioned to perform new functions. This institutional component can consist of rules, practices, norms and relationships. Everyday challenges are the stimulus that moves the institutional bricolage. This processes thus results in "organisational forms of institutions [.... that] often exist for multiple purposes rather than the single-purpose institutions" (Jones 2015, p. 69). The cases of various muro established by the Tokajaeng over time, as we will see, reflect this process.

Related to institutional bricolage is the concept of "legal pluralism." That is, a situation where varied frameworks of rules are applied to similar groups of people and areas (Gupta and Bavinck 2014; Nyenyezi Bisoka 2019). In legal pluralism, power relations is an important factor to reveal why certain normative frameworks are more legitimate than others. Importantly, in this case the power dynamics are exercised not only through conscious forms but also implicitly, where the agenda has been set by the dominating regime, and left the subordinated framings with little room to voice their concern or to try balancing power in their favor (Nyenyezi Bisoka 2019: 3). Hence, while the Tokajaengs may be able to retain their traditional norms and rules in resource management, through time they have to negotiate normative frameworks with more powerful regime such as the government and international organizations.

To apply the critical institutional framework to our case of the Tokajaengs, first we take into account the socio-historical dimensions of the selected case study, placing the broader structural contexts that shape the commons. In this light, this research understands that commons can extend from local to global systems (Saunders 2014; Jones 2015; Chikozho and Mapedza 2017). For example, although the local institutional arrangements shape the local rules that define livelihoods access and conservation, broader interest in conservation from regional and international institutions can result in the support for obtaining resources that affect local institutional mechanisms. This is mostly understood as international NGOs that invest in protecting resources in the long term but could also take the shape of new development imperatives from the state and private sector. Second, our approach explicitly recognizes the interplay between formal and informal 
settings, the influence of longstanding (or revived) traditional management considerations, and modern influences. A commons can be managed outside of the state and among the private sphere, although it is also open to state intervention to some degree (Bollier 2014). Alternatively, a commons can even be seen as a public good managed by the states (Harvey 2011, Shaw 2014). Our case situates the Tokajaeng case therein. Third, the study recognizes that institutional complexities are embedded in daily social life, namely as a resource among users/managers that are socially embedded. Therefore, our explores the norms, values, and interests of different actors at different governing scales (Cleaver and De Koening, 2015). Fourth, the resulting power relations we identify show internal exclusions within the proprietor groups themselves, which may or may not include users. This is because a commons is not only inclusive and progressive, but can also be regressive and exclusive (Bakker 2007). Our approach does not assume homogeneity within communities and pays attention to the 'democratic political space' for the most marginalized group in public decision making processes (Shaw 2014). As Mosse (2006) has also argued, collective action can be supported by ranked social relations, and thus links to wider systems and layers of state bureaucracy that provide legitimation to local authority that allocate productive resources, a factor we also take into account.

Our overall approach will help to examine the historical background and broader processes that shape the muros of the Tokajaeng community, examining the different type of rules and norms as well as organizations (formal and traditional) involved, and the resulting power relations within the institutional arrangement governing the commons. Understanding all these features will shed light on (i) how broader political and ecological dynamics shape and situate the institutional arrangements governing the Tokajaeng customary area, which in turn shape the muros; (ii) how the muros work to protect local ecosystems while providing economic benefits for the people; (iii) how varied actors, rules, and norms interact, how they conflict and are negotiated with different outcomes and/or the nuances that shape new trajectories. The historical dimensions will be reflected through three cases of establishment and enforcement of muro, which represent three different periods. The cases will be presented in order to show the variations over time. This approach will allow for a view that appreciates the commons as something dynamic, socially embedded, political, and nested within the broader frame of governance.

\section{The case study: Lembata, East Nusa Tenggara}

The island of Lembata is a rich biodiversity region and a host to different types of protected and endangered species, such as the dugong and sperm whale, as well as coral reefs that are increasingly gaining attention for international tourism. The island of Lembata is also a region that is known for historically complex environmental conflicts such as betwen whale hunting communities protecting a way of life and international NGOs interested in protecting key large species (Nugroho et. al. 2018: 74). In light of these external generalizations and interest about the region, we explore how local institutions in Lembata emerged to develop mechanisms for conservation. We also believe that a closer examination of local institutional practices can help to develop better joint management opportunities that involve outside support, while also responding to local community concerns.

This study thus examines the local traditional institutions in the customary area of the Tokajaeng, which is located across two villages: Lamatokan village and part of the areas of Lamaau village. The fieldwork focuses on the area of Lamatokan village, located on the north side of Lembata Island and at the western tip of the Gulf of Hakadewa (See Figure 2). The total population of the area is 1,144 and most work as farmers. The Tokajaeng community has local traditional institutions to manage their common pool resources (CPR), which apply to both terrestrial and marine contexts. The CPRs refer to sufficiently large resources that it is difficult or costly to exclude people from accessing them, but use reduces resource availability for others. They can be tangible resource units like forests and fisheries or intangible ones such as knowledge and the atmosphere (Ostrom 1990; 
2010). Closely related to CPR is the concept of the commons, here understood as a sum of CPRs and a system of social relations (including institutions and practices) that manage the CPR (for further conceptualization of the commons, see Euler 2018).

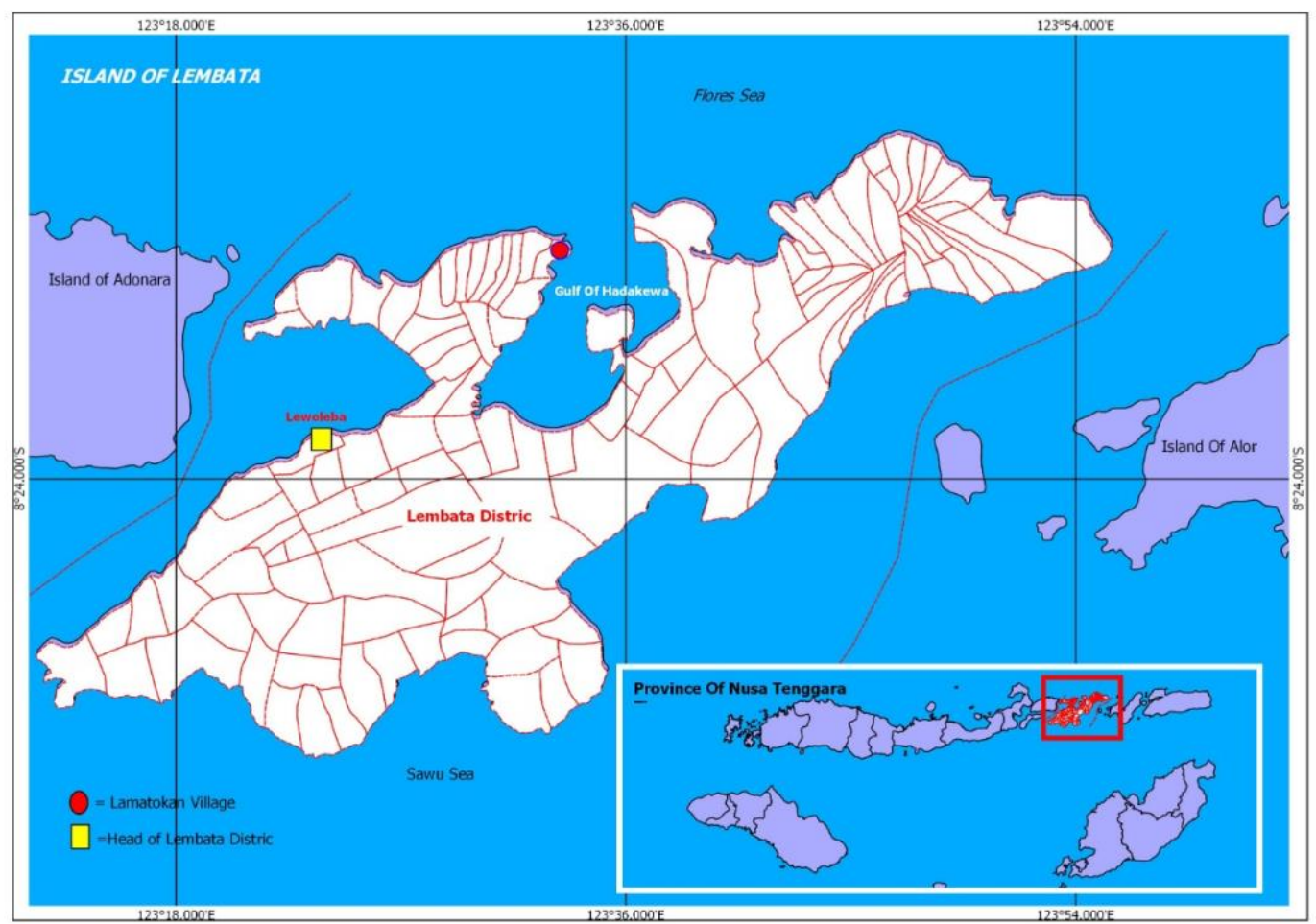

Figure 1. Map of Lembata Island and Gulf of Hakadewa

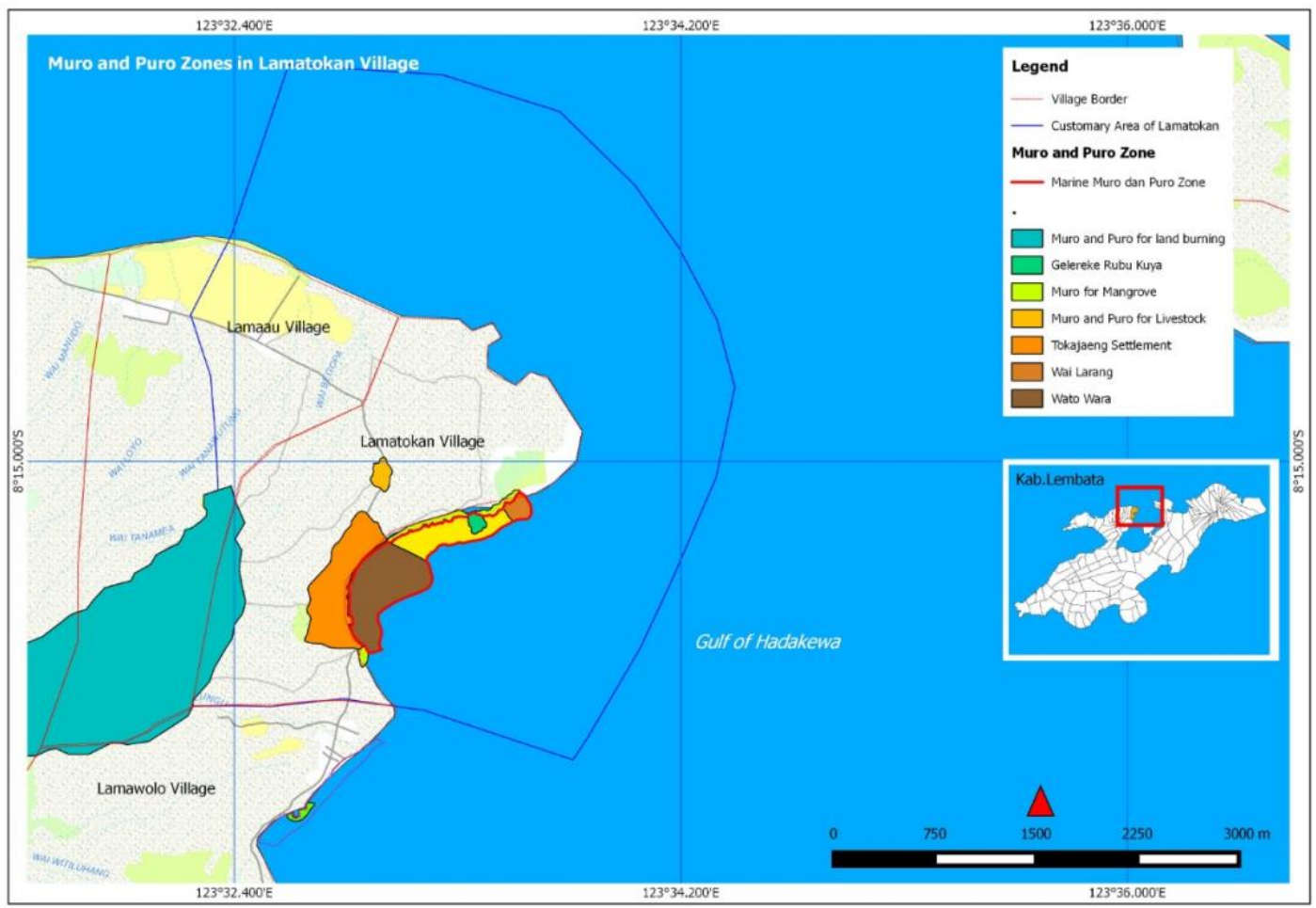

Figure 2. Map of the Tokajaeng customary land and coastal areas, administrative boundaries, and muros. 


\section{Methods}

We draw our conclusions based on fieldwork that comprised of participant observation, complemented by an FGD, and 25 in-depth interviews with key informants (both men and women), such as village head and former village head, fishermen, members of customary institution ( $i k u$ koten megu megang), district marine and fishery official, members of village representatives. The fieldwork was conducted in April, 2019. The research approach was conducted in three stages

1) We began by seeking to understand the various environmental rules (muro) that emerged among the community, specifically the relationship between the establishment of the rule relative to a particular environmental threat.

2) The research thereafter identified whether the muro was a longstanding rule or one that had undergone changes, which created established new mechanisms to address an emerging type of environmental threat. The different sites were also mapped in a participatory approach to understand the geographic extent of each muro, following engaged methodologies to produce research beneficial for the community.

3) Finally, through active participant observation, the second author joined a muro meeting to re-evaluate the extent of the marine muro. During the meeting the second author was asked to help the local NGO in creating a map for the extension of the muro zone, which is done together with the village government and customary institution representatives.

These three phases together identify the mechanism of the muro, the spatial distribution of the different types of muro, and the processes of change that the muro undergo. In this way we are able to gain a holistic picture of local values and their institutional contexts for making decisions about the commons.

\section{Results}

\subsection{Background on the Tokajaeng traditional institutions}

The Customary Land of the Tokajaeng covers the entire administrative area of the Village of Lamatakon and part of the Village of Lamaau, District of Lembata. Its north and south borders are marked by the noan (a kind of stone signpost), whereas Mount lle Lewo on the western border, and on the east site the Hakadewa Gulf at low tide marks the other corresponding boundaries. The Tokajaeng are divided into two classes, which are based on groups of clans. The first group is the lewotana, which are the owners of customary land, who possess the inheritance rights and can make claims to positions of authority as traditional ritual leaders as well as government positions. Second, the nobobelen, or the immigrant clans are granted rights to use parts of customary land by the lewotana. Therefore, the use and management of resources within customary land are under the rules devised by the lewotana clans. It must be noted however, that the relationship between the lewotana and nobobelen is not an absolute or given hierarchy among the clans, since a member of the lewotana clan can be a nobobelen if he/she live in a neighboring village. This system creates a balance of power among clans, and seems to be able to avoid potential arbitrary acts of the lewotana toward nobobelen clans in a village; one can argue that such acts can trigger retaliation towards their clan members who are nobebelen in other villages.

The lewotana clans are divided into three sets of clans based on the birth sequence in the original family, and each of these clans are assigned different functions. The clans descended from the first child, kokomaking, produces the ritual leaders and his deputies. While the ritual leaders are called koten, their deputies are called iku (the tail) mege (left hand) and koge (right hand). The clans from the second child, bomaking, supply the government leaders and his deputies; the leader of the government is called beleng lewo and supported by the kapita duli for affairs on land and kapita 
sarilewa for affairs concerned with the sea. Hence the role of the traditional government to manage the customary land is divided into two sets of affairs: the sea (headed by kapita sarilewa) and land (by kapita duli). And the clan of the third and last child, bidomaking, is predestined as the deputies of traditional government and ritual. The rituals are conducted at namang while the government activities centered around sabangun, specific areas usually have a building for rituals and public meetings. This structure, however, is not always consistently applied in practice. For instance, the bidomaking (third) clans are not always included as deputies of the koten in certain rituals (as $i k u$, mege and koge), or as deputies of beleng lewo (kapitan duli and kapitan sarilewa). But other parts of their rights as members of the lewotana are always respected.

A relevant and important deviation from the traditional rule is related to the selection of traditional leadership, which some effects on the Tokajaeng traditional institution throughout history. In the 1930s the Dutch colonial government appointed a village (kampung) head who was a non-member of the bomaking clans. It was a time that Jacqueline et al. (2017: 4) describes in which the colonial government

"... adopted the pragmatic policy of allowing villages to govern their internal affairs according to their customary (adat) law, and implicitly provided legal recognition of adat institutions within the village boundaries. The village head had a dual role: he served as the head of the community and the representative of the colonial government at the same time." (Jacqueline et. al. 2017, p. 4)

It was also a time when the church started to expand to what is today Lamatokan village. The appointed village head was among the first to be baptized and was also the one who granted his land for the construction of the first church in the area. This appointment created a precedent that the beleng lewo, the head of customary affairs (and then the head of formal village government), could also come from a member outside of the bomaking clan. Here the Dutch government retained the traditional institution (beleng lewo) but not the authority to select the leadership. In mid 1960s, the context of Indonesian government authority also began to shift as an authoritarian regime took over the power with General Suharto became the president, and in Tokajaeng, authority between two separate customary lands (Lamawolo and Tokajaeng) merged into one village, Lamatokan. This merger took place to avoid conflict over the right to become beleng lewos of the new village. Lewotanas look back at the past colonial example and appointed another non-bomaking clan member as a village head. These precedents re-emerged when the traditional institutions were subordinated under the New Order regime, with consequences on the customary institution's role in protecting the local ecosystems (see Case 1: land and forest muro in 1978).

As soon as Suharto became the president in 1967, the process of centralizing power to the national level began with a series of regulations. Suharto's regime created a long line of clientelistic ties from the central down to the village administrations, which undermined local control of the local and/or customary institutions. The Suharto system shifted decision making processes based on the village head, while undercutting the customary election systems, which was also accompanied by severe repression by the military. This also resulted in a dependency of $x x x$ from the national budget, while dismantling traditional local claims on resources through customary land (Kahin 1994, Rachman 2017). Law No. 5 in 1979, established the village government as the lowest administrative level of the national government and mandated this uniform entity nationally (Jacqueline et al. 2018). In Lamatokan, these changes meant that the village residents lost most of their power through customary institutions as the traditional governing authority. All land under village jurisdiction, for instance, was largely put under the formal authorities so that customary lands could be taken for state development programs. The village heads were elected by the population but had to be approved by, and then report to the district heads, which were themselves posted as representative of provincial governments. The village head held formal authorities for rulemaking and planning, but mostly in a top-down manner, receiving instructions on how to apply governmentrun programs from upper level instructions. 
Law No. 22/1999 changed the political position of the village relative to the supra-village government, and also changed the role of the village assembly to an executive body. The village administration thereafter had greater authority to devise a plan and draft rules, and can choose to incorporate a model of government by adopting customary institutions. The village head has since reported to the village assembly who has the authority to impeach the village head. By this time, the indigenous peoples' movement and discourse had also reached a high point. National level campaign to recognize the indigenous communities became stronger with the establishment of a national alliance of indigenous people (Aliansi Masyarakat Adat Nusantara, AMAN) in 1999, followed by more intense campaign in many places by members of $A M A N$ and supporter NGOs (Peluso et. al. 2012). The new decentralization law no longer put the village at the bottom of administration hierarchy. The patron-client ties among actors within old regime that spread down to village level was in turbulence as the national regime underwent substantial change (Jacqueline et. al. 2018). These developments provided for more authority to the customary institutions in Lamatokan to govern their customary areas. It is in this light that the muro, namely the rules that help to regulate natural resource uses present the opportunity to shape new ways of thinking about conservation.

For the current Tokajaeng, all prohibitions are generically called muro. However, examining the muro more closely indicates that they can actually be divided into various subcategories that represent different types of prohibitions. These include:

(1) gelarake (prohibition based on sacred place),

(2) nao (prohibition related to kinds of totem),

(3) haru (taboo),

(4) murung (adopted prohibitions based on formal state regulations), and

(5) puro (prohibition with sacred oath).

Although these are all some forms of muro prohibitions, the main aspect distinguishing them from one another is the process through which they are established and the corresponding type of sanctions. Rituals associated with muro enforced with a puro oath undergo changes as the formal village government rules were enforced on the Tokajaengs. This change includes customary rules related to the structure and actors of the rituals for natural resource protection, although their basic function as a prohibition for certain zone remains.

\section{Case 1: A muro against the burning of forest and land}

The case of muro with a puro oath to prohibit the burning of forest and land to open cropland took place in 1978. The case shows how the endogenous institutions of the Tokajaeng were able to establish a muro against the burning of land even when the New Order governance system effectively took over local positions of authority. Since the early 1970s, a combination of swidden agriculture was practiced and as the population grew, acute deforestation began to take place around the mountain of lle Ape. ${ }^{4}$ Lamatokan is located on the eastern foot of the mountain. The clearing during that period was so intense that the local people begun to buy perahu (boat) from outsiders since most of the large trees around the village, the main material for the local boat builders, were burnt. Another important effect of this transition was that the cropland also became prone to fire. The practice of burning to clear new cropland after years of fallow often ended with wildfire that spread to neighboring lands and burned their crops, notably corn. After a period of several repeated harvest failures, the conditions led many of the village population to migrate in search of alternative livelihoods. A local NGO activist noted that in the 1980s, many of the village families depended on migrant remittances.

\footnotetext{
${ }^{4}$ More detailed research is needed to explore the dominant causes of this depletion of land and forest during the 1970 s.
} 
The deterioration of the forest and land conditions around the lle Ape Mountain gained the attention of the provincial government. In 1976, the provincial government held a public murung meeting attended by representative of people surrounding the mountain. At the end of the meeting the governor asked the village government to ban the burning of land and forests to open new cropland. The Lamatokan village government then held meetings to extend the message within the village. An agreement was reached and preparations were made to define the protected area. The muro ritual to prohibit deforestation and land burning was held in 1978, and still applies today.

This case represents how the locals responded to an environmental threat, but also how a local institution can work under a top-down and centralized governance system during the New Order period that effectively took over political authorities from the customary institutions.

The effects of this change are multiple. In the lewotana level, conflict ensued. Three different clan groups within the lewotana (bomaking, kokomaking and bidomaking) competed with each other for the new formal power (formal village head), resulted in violations of traditional distribution of authority among them. Since the formal heads are decided by elections, any clan groups with the ambition and enough constituents will dominate the popular vote. And in Lamatokan, the nobobelen have always had larger populations than the lewotana, indicated by the fact that more of the former clans reside in the village than the latter (see Table 1). Therefore, the Nobobelen dominated five of the successive village heads in the period 1979-2005, instead of the bomaking as traditional clan for customary government leaders (See Table 2).

Table 1. Clans and Status in the Tokajaeng Community

\begin{tabular}{|c|c|c|c|}
\hline Clans/Kinship lines & Status & Clans/Kinship line & Status \\
\hline Kokomaking & Lewotana & $\begin{array}{l}\text { Wanganaing from } \\
\text { Lamawolo }\end{array}$ & Nobobelen \\
\hline Bomaking & Lewotana & Domaking from Baopukan & Nobobelen \\
\hline Bidomaking & Lewotana & Berewu Making Lamawolo & Nobobelen \\
\hline $\begin{array}{l}\text { Purlolong from } \\
\text { Lewohala - Jontona }\end{array}$ & Nobobelen & $\begin{array}{l}\text { Hali Making from Lewohala- } \\
\text { Jontona }\end{array}$ & Nobobelen \\
\hline $\begin{array}{l}\text { Kaliku from Kalikur - } \\
\text { Kedang }\end{array}$ & Nobobelen & $\begin{array}{l}\text { Soro Making from Jontona, } \\
\text { Kelela One from Lewo } \\
\text { Tolok }\end{array}$ & Nobobelen \\
\hline $\begin{array}{l}\text { Lewotobi from } \\
\text { Lewotobi - lle Bura }\end{array}$ & Nobobelen & Lamaau from Lamaau & Nobobelen \\
\hline $\begin{array}{l}\text { Atawatung from } \\
\text { Atawatung - } \\
\text { Lamagute }\end{array}$ & Nobobelen & Ladopurap from Lewotolok & Nobobelen \\
\hline
\end{tabular}

The village consultative institution (Lembaga Musyawarah Desa, LMD), an element under the structure of the formal village governance, represented another form of subordination. By law, this institution comprised of representatives from village leaders and professional organizations, but also involved the formal village head and its whole staff, and was led by the village head himself. The traditional customary leaders in Lamatokan were included as members of the LMD. This structure impeded the $L M D$ function to represent actual villager aspirations (Saragi 2004), although it did not strip the legitimacy of the traditional institutions among the people themselves. 
Table 2. Village heads and their respective muro and puro, since 1972

\begin{tabular}{|c|c|c|}
\hline Rules Enacted & Village Heads & Tenure \\
\hline puro burning & Philipus Bidomaking & 1972-1982 \\
\hline \multirow{3}{*}{$\begin{array}{l}\text { marine muro, proposing a puro; } \\
\text { puro for livestock (without oath) }\end{array}$} & Mikhael Tugu Pureklolon & $1982-1984$ \\
\hline & Yohanes Riang Bomaking & 1984-1992 \\
\hline & Lukas Demon Pureklolon & 1992-1999 \\
\hline \multirow{2}{*}{$\begin{array}{l}\text { Muro with puro for livestocks } \\
\text { with the establishement special } \\
\text { area for range (2005); marine } \\
\text { muro dan puro (2005) }\end{array}$} & Mikhael Sada Kalikur & 1999-2013 \\
\hline & Yohanes Subari & 2013-2014 \\
\hline $\begin{array}{l}\text { Extension of marine muro with } \\
\text { puro to the gelarake zone (June } \\
\text { 2019) }\end{array}$ & Mikhael Mari Pureklolon & $2014-2020$ \\
\hline
\end{tabular}

Hence, from a villager perspective, the traditional institutions existed only in their minds rather than in the real world, as it was formally paralyzed by Law No.5/1979. Although the actual authorities had lost, most of the Tokajaengs still acknowledged the traditional rules, such as the leadership selection system for different functions in traditional institutions and their related rights to establish traditional rules and sanctions within the customary lands and coastal/marine areas. This granted the niche for the customary institution to hold on to passive functions to some extent. For instance, although the formal authority of the village head was clearly politically stronger, the arrangement and usage of local resources of customary land by the village government still involved the traditional institution, especially the clans of the lewotana.

The establishment of a muro for land and forest burning took place in this context. Coincidentally, the first formal head of village under the New Order came from the lewotana clan. Therefore, he led a relatively smooth process in the establishment of a muro, and enforced it with a puro. It only took him about two years between the initial idea and the enactment of the muro (1976-1978). An 'unintended' recognition of the pacified customary institution, which occurred as a coincidence, made it so that they could resolve internal conflicts among the clans. This establishment also helped to retain or prolong the muro ritual among the local people; and the recognition consequently determined the success of the muro. During this suppressed period, when the village head did not come from lewotana, several rules such as the prohibition to allow livestock to roam (cow, pig, and goat) were established by the village government but did not carry traditional sanctions enforced by a puro oath. During this period the Tokajaeng appeared to be unable to find ways to synchronize the two different authorities, and conflicts ensued. Perhaps they failed to do so since the authorities lived outside of their reach, far away at the district level. Meanwhile in the nobobelen clans themselves, who represented a large portion of the village residents, there was disobedience to prohibitions established by the formal village government without a traditional puro oath.

This case shows how environmental threats over the Tokajaeng commons (i.e. land and forest burning) coincided with a top-down call from the governor, and prompted the customary institution to establish prohibitions. The success of the establishment and enforcement of this muro (with 
puro), although took place in the suppression period of New Order regime, owe to the respect for the traditional prerequisites-albeit unintended. The village head came from a suitable clan so the muro and puro ritual could follow accordingly. The muro were strengthened with an oath believed by local people to bring severe penalties to violators. This illustrates how 'socially embedded' rules based on local norms and beliefs were more powerful than formal, even coercive rationality. A message from a centralistic, top-down, and oppressive regime to protect against environmental threats in this case could only be successful so long as the traditional institution could function properly. This case also shows the interplay between formal (i.e. Indonesian government) and informal customary institutions that shaped the actual workings of the commons governance systems of a previous generation. In the following decades, after the New Order regime fell, the formal-informal governance interplay produced different kinds of institutional arrangements to face other types of environmental threat, which we turn to next.

\section{Case 2: A marine muro against extractive fishing}

This case describes a protracted process to establish a muro to protect a marine zone against extractive fishing. The New Order established, both through regulations and clientelism, a system that connected the president to village heads (Jacqueline et. al. 2018). In many cases such arrangements violated the traditional rules and resulted in internal conflicts within the Tokajaengs and impeded the establishment of muro. However, following periods of significant national political change, in 2005 a revival of indigenous institutions began to take place for the Tokajaengs. They gained stronger authority in regional legal frameworks, which was supported by legitimation in public discourse.

Unlike the earlier muro case, establishment of a muro within a customary marine zone in Lamatokan went through a protracted process. The idea to place a ban on the zone developed when fishermen from outside the island increasingly used bombs and poison to fish throughout the Gulf of Hakadewa. When the bombing by Tokajaeng villagers began in the early 1980s, no one knew about the potential impact until around 1985 when the catch volumes began to shrink significantly around the customary waters within the gulf, and people had to go further beyond the area to fish. This was also true for the impact of poisoning to catch lobsters and smaller prawns. This practice not only forced the lobsters out of the reefs, but also killed much of the reef areas. The new fishing practices that the locals adopted from outsiders were done to get higher catch in a shorter period. The adoption also effectively changed the livelihoods of some local families. The villagers were previously subsistence fishers with much more time dedicated to farming (crops and livestock), and the adoption of these practices to quickly amass a large catch, attracted part of the peasant families to become fishers. ${ }^{5}$

In 1985, facing these increasingly pressing environmental challenges throughout the gulf, the village head invited the ritual head and his deputies (iku koten megu megang) to a meeting to discuss the possibility of banning bombing and poisoning practices in the area in front of the Tokajaeng village. In the village office (sabangun), the meeting decided to establish a muro zone in the sea area (right in front of the village coastline) extending from the north to the south end of the village. Meanwhile, traditional fishing activities that used traditional tools, such as fishing line, suluh (light and spear), bubu (fishing pots), were still permitted. However, the muro reinforcement with puro ritual could not be conducted because of an internal dispute that ensued within the members of ritual holders (iku koten megu megang) over the rights of 'the first birth' (hak kesulungan) in leading the ritual. This was so because the beleng lewo (head of the traditional governmental institution) no

\footnotetext{
${ }^{5}$ Lamatokan Village statistics (2019) stated that there are 40 people out of $1,144(3,4 \%)$ who work as fishers, while those who work mainly as farmers (including livestock rearing) and occasionally fishing amount to $50 \%$ of the population.
} 
longer possessed the authority over public affairs since the formal government system had taken over most of the traditional institution's authority.

During the 1980s, the structure of the traditional institutions no longer functioned as a formal government, and though further weakened by internal conflict, remained intact. As a result, because this 'marine muro' (muro laut) was without the enforcement from a traditional oath, it was only the state law that worked to enforce the muro, with the captured violators sent to the marine police (Polairud). Therefore, while the 'weak' muro provided the perimeter boundary, its enforcement was covered by the state agencies such as marine police and the local marine and fisheries office, which then played some role in preventing further destructive fishing practices.

The muro establishment worked effectively to stop the bombing within the muro zone, but such activities were still operating outside the protected area. In the early 1990s, a new environmental threat appeared. Purse seine fishing began around the area and involved some of the local villagers. Since this practice was not yet included in the muro or in the list of prohibited gears by the formal government, the practice began to grow rapidly. The usage of the new tool soon diminished the fish population significantly which had been growing back since the bombing and poisoning was banned. The village head then renewed the terms of the rule, making the purse seine as another gear prohibited within the zone protected by the muro. The result was that the fishermen covertly used the purse seine, and they did so because it was not yet sanctioned by traditional rule. A puro oath ritual was still required for this particular (renewed) muro to be complied by all the Tokajaengs: a muro without a puro oath was insufficient. This destructive practice continued until 2005, when the puro oath was finally made in the namang against the bombing, poisoning, and seine fishing. Since then the Tokajaengs stopped these destructive fishing practices.

The marine muro was initiated since 1985 , but only established with a puro in 2005 . There were two main causes for the protracted process. First, the head of the village in 1985 did not come from the lewotana clans. Second, inter-clan conflict ensued over rights to be koten (ritual leader), between certain bomaking and kokomaking members, which took place after the bomakings lost their political authority to be beleng lewo. The suppression of the customary institutions had caused an overall loss of authority, creating disobedience and internal conflicts among clans, and finally prompting degradation of the marine biodiversity within the Gulf of Hakadewa that lost most of its coral reefs and sea catch.

However, under these challenging political conditions, the customary institutions still held on to their legitimacy over customary land and traditional rules and sanctions. Periodical meetings and/or rituals around commons protection and use (i.e. forest and land muro) seems to nurture endogenous institutions, including a reaffirmation and socialization of norms and values related to the commons (e.g. Olin Wright, 2011). The customary structure remained respected by the Tokajaengs. This relationship contributed to the ability of the traditional institutions to bounce back and adapt during the new political transition that was taking place nationally, namely following the fall of New Order in the late 1990s.

The prolonged dispute over who holds the authority to lead the puro oath ritual was only resolved when different types of institutions (i.e. formal government and customary institution) held a large meeting in the village office to clarify the first birth clan in order to identify who has the traditional right to lead the puro ritual. After a long debate and proceedings for clarification, it was settled that the right goes back to one of the kokomaking clan, and that the ritual can be held after not being practiced for almost 20 years (1978-2005).

This arrangement was possible after national political change, which was followed by the transformation in the general public view of indigenous groups, which was also accompanied by supporting legal structures. The success of the marine puro in 2005 strongly related back to the rehabilitation of customary institutions. Our informants in Lamatokan mentioned that the passing of national Government Regulation No. 72 in 2005 on the Village Government was one of the signposts of the re-emergence of village autonomy, which was then strengthened by national Law 
No. 6 of 2014. Following these regulatory developments, customary institutions (Lembaga Adat) were established in Lamatokan, and became a part of the state governmental structure at the village level.

Some informants called this new arrangement as a 'transplant' of traditional structure into the formal one. The new institutional arrangement created strong legitimacy and authority for the customary institution as it consists of representatives from both lewotana and nobobelen, hence included all the clans within the village. With the establishment of the Institution, traditional roles of the beleng lewo were restored. The actual and formal rights over the customary land because of the customary institution, following traditional rules, revived the position of lewotana clans who are now actually in control customary lands. Since then, the usage of customary land for public facilities, for instance, requires a permit from the customary institution before being implemented by the formal village government.

The distribution of authority and arrangements between the formal and customary institution within the village can be described as follows:

(1) Legislation works by drafting village rules and planning, which are carried out by the PMD (village assembly, representative of all residents) and formal village government.

(2) The control, management, and use of all resources within the customary land areas are under the authority of the customary institution. The Institution can ask the village head and the village assembly to discuss and issue formal regulations about any usage of such resources.

(3) Finally, when a village regulation needs a puro oath to strengthen it, the customary Institution will decide, prepare and undertake the ritual.

This arrangement provides structural support for the establishment of the marine muro. With the new arrangement, the customary institution can now decide, and the village head announces the day the puro is to be held. The koten (head of ritual) with his deputies prepare the rituals in namang, which include a cock, banana, and wine, which are also provided by the community members attending the ritual. Unlike the puro rituals of the past, those who sit in the circle surrounding the ritual center are as follows: koten, kege, mege, iku, kaputan duli, kapitan sarilewa, and new elements have been added: the village head and the head of the village assembly. All other ritual elements remain the same: the cock blood is spilled on to the tree and stone, a ritual performed by the koten, and the puro oath is announced to forbid bombing, poisoning, and seine fishing, as well as a fine of a goat or mature pig for violators. After the banquet, the ritual proceeds to the muro zone with the planting of nikes, meaning that the muro area has been established and reinforced with a puro oath.

\section{Case 3: Extending the marine protected area}

The third and final case involves a muro for mangrove protection, which highlights how new institutional arrangements supported innovations in the application of muro. With the new institutional arrangement, not only were past internal conflicts settled, but further innovations are unfolding, including those to protect biodiversity with muro and invocation of the puro oath. The new authority of the customary institution also led to further innovations that involved new institutions, actors, and types of knowledge. The case in point is an initiative to plan an extension of muro and puro for the marine protected zone. ${ }^{6}$ This initiative strongly related to an intervention carried out by a local NGO, Barakat, supported by Burung Indonesia. Barakat, supported through international donor support, conducted an evaluation on the marine muro and puro in Lamatokan through a survey on ecological conditions of marine areas of the village in 2018. The survey shows an improved condition of the coral reefs and high diversity of fish within the muro zone, indicated by the growth of new reefs and increased fish populations. But for local people, the most surprising

\footnotetext{
${ }^{6}$ The muro banning mangrove destruction was initially in place in the 1930s, when the beleng lewo was not held by a bomaking member.
} 
finding was regarding reefs within the gelarake zone of Rubukuya. Although the area was not within the demarcation of the marine muro area, the local people considered this area as adjacent to the gelarake zone. Based on these findings, several community members, mainly the village government and members of Barakat, advocated so that the gelarake area also be included in the muro-puro zone, meaning that the current muro zone should be extended to the north in order to include the gelarake zone in Rubukuya. (See Figure 2)

However, not all parties accepted this idea, especially the fishermen who own boat and seines. They argued that the extension will decrease their livelihood sources because the usage of the seine would also be banned within the zone. An elderly fisherman informant with a different opinion expressed that in reality the Rubukaya need not be included in the muro and puro zone, because they are carefully fishing (using seine) in the area because the current is usually so strong that it often rips the net. The cost of a ripped net is much higher than the catch they can normally acquire. Several meetings to discuss the issue did not produce meaningful decisions. Finally, in April 2019, murung discussions on the extension of marine muro-puro were held in the village office, attended by around 80 people. It involved all village office staff, customary institutions, village assembly members, a representative of the navy, and local fishermen. In the four-hour meeting, the plan to extend the muro zone failed to reach agreement. It was only two months later, in June 2019, that there was agreement to extend the zone.

Another innovation also occurred during the temporary ban lifting or 'opening' periods of the marine muro, involving adaptation of rising needs and new government rules. The first muro opening process originally took place in June 2006, when some community members asked the muro zone to be opened because of their needs for fish, which were rising since more traditional customary rituals had to be held by the community. The idea was discussed among the head of the village, village assembly, and the koten, with his deputies. The village government then asked the koten to lift the muro ban for a month, with a daily duration between six in the morning to six in the afternoon. Otherwise the violator will be fined with a mature goat or pig. The muro and puro opening ritual was done in namang, similar to the puro ritual. At night, after the ban lifting the ritual, the village head announced to citizens to prepare for the physical in situ opening of the puro the next morning. In 2007, the opening of marine muro for the third time came with a levy set up by the formal village government. By that time, under a new law, each village government is expected to raise their own village income. Fishermen therefore bought coupons printed by the village government at $\mathrm{Rp} 50.000$ per coupon to gain a permit to fish temporarily in the opened zone. This also only applies for those who agree to fish only using gill nets.

The traditional enforcement is strongly respected by local people not only because they feared the potential penalty of the puro oath, but also because it is enforced with traditional graduated sanctions, and furthermore, provides rapid, accessible, and affordable conflict resolution mechanisms (c.f. Ostrom 1990). In 2006, for instance, a fisher secretly set up his seine at night within the muro zone, but another fisher using fishing lines got his hook stuck in the perpetrator's net. He reported it and a court for violating the muro immediately carried out the sanction at the village meeting hall. The customary court convened and was attended by the head of the customary institution represented by the koten in the formal meeting. ${ }^{7}$ The fisherman was fined and a goat was killed at the namang. After the court, no other offenders have since violated the marine muropuro.

\section{Discussion}

Following the critical institutional approach by Cleaver and De Koening, 2015), we have shown the importance of the socio-historical formation of institutions through the three muro cases,

\footnotetext{
${ }^{7}$ By the end of 2005, the government formalized the customary institution. It comprises of five representatives from each hamlet within the village.
} 
connecting their establishment to the influence on local people governing their commons. The first and second cases indicated that the extent to which the Tokajaeng were able to apply traditional institutions partly depends on the broader multi-scale institutional arrangement and the resulting power relations. When the interests of the Tokajaeng coincided with the formal institutions like in the first case, the muro can be established in a relatively short time, and have long term effects. Importantly, this only became possible when the Tokajaeng were able to retain traditional values and beliefs as negotiated by their customary institutions. Although the traditional institutions faced immense obstacles during the New Order regime, threatening their traditional authority for a protracted period, it created forms of local disobedience and internal conflicts in resource management. One important factor that helped to retain customary institutional authority was the occasional meetings and rituals around commons protections and uses. In times of suppression, these traditional events provided a lifeline for the endogenous institutions by way of reaffirmation and socialization of norms and values related to the commons. This was symbolically and institutionally remediated through a muro against the burning of forests illustrated in the way that customary rules were actually responsible for the success of formal calls to prevent wildfires. Thus, the case shows the importance of the traditional rules, namely the socially embedded institutions with different kinds of rationality and beliefs, embraced by the Tokajaeng.

Meanwhile, in the second case, whereby formal institutional suppression of local customary authority created substantial fragmentation among the Tokajaengs. As a result, the muro could only be established after the fall of the New Order regime that paved a way for more flexible formal institutions through new legal and power structures. This national political change and the effects in the Tokajaeng community provided leeway for an international campaign on the recognition of indigenous people and subsequently the empowerment of local and customary institutions amidst formal regulatory processes, supported by a large network of civil society groups. The result among the Tokajaengs translated into the opportunity to rehabilitate older traditional institutional practices and shape the into new forms that were re-established among formal and informal authority locally.

The cases also indicate that the phenomenon of legal pluralism is taking shape in villages in the form of institutional 'hybrids' (Gupta and Bavinck 2014). As the traditional values are re-established and empowered, the customary norms and organizing structures continue to hold legitimacy among people, which determine Tokajaeng obedience towards the muros. As soon as formally allowed in national laws and regulations (See Davidson and Henley, 2007; van der Muur et al., 2019), parts of these customary organizational structures and rules (like the muros) were then adopted to the formal village rules. This institutional fusion displays, in a legal pluralism viewpoint, how the current institutional arrangements can overcome the incoherence between normative systems, negotiating between formerly formal and informal rules, and thereafter applied to similar groups of people and territories (Gupta and Bavinck 2014; Griffiths 1986).

The hybrid system is particularly prominent in the third case. With more authority devolved to customary institutions by the new laws and regulations, changes also followed in the power relations for managing public affairs at the village level. With more power for the traditional institution, the surviving traditional values gain more room for maneuver. From the vantage point of the Tokajaengs this translated into greater legitimacy than the formal administration in the village level. This development allows the customary institution to set the agenda for rules and policymaking at the village level. Several new village formal rules are decided in meetings following a customary approach. Thus, the traditional institutions actually create a hybrid institutional arrangement by adopting new institutional mechanisms (relevant formal rules and structure) as they face new ecological and economic challenges, or receive new knowledge about them. This case reflects that not only do the power relations become an important factor in revealing why certain normative frameworks is more legitimate than other (Nyenyezi Bisoka 2019), but also determines which rule framework has more authority to determine what formal rules to be issued. 
The cases also reflect the practice of "institutional bricolage" where the Tokajaengs modify institutional arrangements by adopting various rules and relationships from elsewhere and which are refashioned to the older ones to perform new functions as they face new ecological and economic challenges (Cleaver and De Koening, 2015). The customary institution, "the organizational forms of institutions ... [now] exist[s] for multiple purposes rather than the single-purpose institutions" (Jones, 2015: 69). The multi-purpose nature of institutional bricolage, institutional improvisation and adaptation, seems to help the Tokajaeng to build the general capacity of communities. The Tokajaengs seems to have the capacity to transcend beyond the community sphere into political processes by influencing state programs and policies to some extent, a phenomenon also documented by Shaw (2014).

Table 3. Types of muro

Gelarake Gelarake means sacred place, and there are many of them within the Tokajaeng customary land, but the one directly related to species and zone protection is the area called Rubukuya, one of the water areas rich with diverse kind of reeds, seagrass, and a habitat for dugong. Fishing activities with gears friendly towards the reefs, like fishing lines and gill nets, are allowed in this area. However, since the locals have known that the area has strong deep water current, one that can drag the nets to the corrals and rip them, it is not a favorite spot for the local fishermen. No customary guards are needed to enact the gelarake. The locals believe that the ancestors are guarding the area, sanctioning the trespasser, in which case they will be cursed by the ancestors if in violation.

Haru This can be understood as taboo. Haru normally relates to temporary prohibitions to consume certain food crops, for instance no corn eating for the oldest man in a clan. Similar to gelarake, the violator is believed to be cursed by the ancestors.

Nao Similar to taboo, but specifically related to totems. For instance, the Tokajaeng considers whale hunting or eating crocodiles as taboo. Several clans within the Tokajaeng community also considers eating sea eels as taboo. Nao is usually related to a totem. Whales and crocodiles are considered as ancestors who are protecting them. For the Tokajaengs, the whales are not only prohibited for hunting but also play an important role in determining planting seasons. The whales blowing while swimming in front of the settlement serve as a sign to start planting corn. Similar to gelarake and haru, ancestor curses will come to someone who violates nao.

Murung The murung have two meanings: first is a mechanism to hold public meetings to plan a muro. Second, murung can also mean to disseminate and adopt formal government rules to be obeyed by community members. In this latter definition of murung, the level of obedience depends on the individual members of the community. Violators of murung are usually penalized by means of formal rules. For example, prohibitions on catching turtles is not part of any customary prohibition but included in the formal rules and enforced by formal institutions. Therefore, the local murung is usually enforced by certain personnel of authority like Kelompok Masyarakat Pengawas (Pokmaswas, Community Patrol Groups), a group formed by the government to oversee the murung protected zone.

Muro In a general sense, all prohibitions of the Tokajaengs are described as muro. But the term "muro" specifically means a prohibited zone. The establishment of a muro requires a public agreement, that are based on a series of elaborate and 'completed' traditional rituals. It is sometimes enforced by sanctions established in a ritual of a puro oath. A curse from violating the puro oath is the most feared among the community members, because the level of sacredness is believed to entail death for the violators.

Puro Puro is part of the muro. While muro regulate a prohibited zone, the puro regulates prohibited activities and things within the muro zone. The stronger puro are the ones enforced by a puro oath that contain possible curse for violators. There are also puro without oaths, such as prohibition to free livestock (which has no specific prohibited zone)

In the context of state efforts applying top-down conservation instruments, the muro shows the value of local institutional authority rooted in local belief systems that can reshape through 
adaptive mechanisms, particularly when it comes to the commons. The endogenous institution governing the commons in Lamatokan seem to strengthen community self-organizing capacities, which then are applied to other innovative programs that came into the villages, such as those brought by NGOs and donor organizations. They can thereafter help to organize public meetings whenever they need to talk about shared issues, setting up agendas or plans, and executing them. Bottom-up planning for the use and protection of the commons would be difficult without this endogenous element, which have to be maintained in a multi-scalar framework to ensure their sustainability (e.g. Chikozho and Mapedza, 2017). The existing commons governance has thus led to the improvement of other types of collective actions while retaining and expanding rules for environmental purposes, including those related to endangered species and habitat protection (see Table 3 for details of rules developed by the local institutions).

It remains to be seen how the current institutional arrangement in Lamatokan will unfold in the future. For example, current recentralization in conservation efforts in Indonesia indicate that institutions responsible for resources are ever-changing (Sahide et al., 2016). More detailed studies are needed to explore how property rights (e.g. rights to access, withdrawal, management, exclusion, alienation) are defined by muro. What bundle of rights are distributed to the community and particularly who in the community retains decision making authority? What is allowed and not allowed and what new forms of exclusion emerge amidst these ever-changing institutions? Such explorations will enable us to delve deeper into the question of obedience of traditional values, which given the breadth already undertaken in this study, remains a limitation that demands further future inquiry.

\section{Conclusion}

The cases in our research show how environmental threats and concerns over the Tokajaeng commons prompted traditional institutions to establish different types of prohibitions. We showed how these dynamics unfolded in three case studies over time, highlighting how potential crises, such as harvest failure, forest fires, and diminishing potential from coral reefs and catch areas, stimulated Tokajaengs to establish muro, enforced by a puro. The first case showed the imbalances and interplay between formal and informal institutions that were common to the governance structures of that time period. Significantly, it showed how the cultural institutions still played a crucial legitimating function behind the scenes. The second and third cases demonstrated that after a long period of suppression, support from a more favorable political enabling environment, the customary institution found new ways to reclaim their authority. These include the ability to re-establish graduated sanctions, institute affordable conflict resolution mechanism, as well as the ability to transcend beyond the community sphere into broader political processes by influencing state programs and policies at the village level. In the current institutional arrangement, the Tokajaengs now practice institutional bricolage by developing a series of innovative programs and rules that can ensure relatively equal distribution of resources that also protects the environment, as well as supporting village government programs.

To conclude, the cases show how historical dynamics of institutional arrangements, from one that weakens to those that provide an adequate enabling environment, significantly affects broader political and economic contexts. Meanwhile, the local interplay between formal and informal customary institutions persists, with the resulting power relations among them dynamically taking shape to govern the commons. With greater authority on the part of the customary institution, the current institutional arrangements for governing the commons in Lamatokan clearly appears to be desirable for the Tokajaeng community. With the muros strongly governed by local norms and beliefs, combined with formal rational sanctions, they create broader legitimation that remains strong in the eyes of the Tokajaengs. Therefore, the institutional arrangement governing the commons in Lamatokan are not only able to adapt to different type of threats, but also seemed to 
strengthen community self-organizing capacities. Applied to innovative programs that come to the village, this ability can further establish new innovations to protect natural resources.

With greater authority, legitimation, and knowledge, the local institutions are able to response to immediate environmental threats, but also provide transformative responses - not only adapting to changing situations but to change the situations themselves. The muro responds reflexively to both internal and external dynamics in protecting the commons. They at once adapt to changes that threaten the commons in a way that each new threat corresponds with a new rule. As a result, we can expect a continuation of bottom-up planning and rulemaking for the use and protection of the commons which are nested in a multi-scalar framework. We can expect that an adaptive local institutional arrangement can help to ensure sustainability of both local conservation and livelihoods. In the context of state efforts applying top-down conservation instruments, the muro shows the value of local institutional authority rooted in local belief systems that can be reshaped through adaptive mechanisms. The muro therefore offer new opportunities for rethinking conservation in the Wallacea region, in ways that can actively engage local authority to devise and enforce rules to protect the environment.

\section{Acknowledgments}

The research was supported by the Critical Ecosystem Partnership Fund (CEPF) through Burung Indonesia. However, this paper solely represents the researchers view, and not necessarily those of CEPF. The writing process was assisted by Forest and Society, and the review and feedback has been very valuable in developing the ideas for this article.

\section{Appendix: The process of muro and puro rituals}

The process of establishing muro and puro took place as follows: First, the beleng lemo as the traditional headmen invited the koten and his deputies to discuss about the plan on enforcing a particular zone with certain prohibitions. In this case they needed a plan to protect particular zones from destructive exploitation. The meeting was usually carried out in sabangun, a traditional hall for public meetings, where the issues discussed and participants share concerns and suggestions to reach agreements, including the time and duration of muro in certain area, the sanctions, and whether they need enforcement with a puro oath ritual, which would be carried out in namang (the ritual center area). The agreement would be announced to the public across the customary area. In case of a murung which was to be established as customary muro, the result of a murung meeting with state representatives will be discussed once again by the beleng lemo and his/her deputies (the kaputan duli and kapitan sariwela) as well as the koten and his/her deputies. Then, on an approved day the beleng lemo and koten, each with their deputies announce the terms of the muro, and a ritual would be held in namang.

During the muro and puro rituals in namang, the important ingredients of the ritual offerings (cock, banana, and traditional arrack wine) are provided beforehand. At the start of the ritual, beleng lewo and koten with their deputies sit in a core circle in the middle of naming. In the middle of the circle there is a big tree and a dolmen-like stone. The ritual is led by the koten, and community members who attended should not be from outside of the center circle (the lewotana clans). The koten would kill a cock and drip its blood to the tree and the stone while stating the puro oath which includes the prohibited activities within the muro zone, and the potential curse or penalty for the violators. The ritual then continues with a banquet, the steamed bananas and chicken (cocks only) and a glass of arrack. But before they drink the arrack they put some drop of the wine to the tree and dolmen, started from the koten then successive ritual participants according to their sequence within the kin network. Parts of the ritual cock are mixed with other steamed chicken provided by attended kin members, and the banquet begins. This usually takes place at early afternoon.

After the banquet, the ritual continues at the actual muro zone with the fixing of nike poles (bamboo poles) to indicate the borders of muro zone. With the completion of this ritual, the muro has been enforced by a puro ritual, the highest prohibition with the harshest possible sanction within the customary area of the Tokajaengs. Thereafter the muro zone is closed, and the nike will not be taken off until a muro opening ritual is held to end the muro duration. Once the bamboo poles rot they would be replaced by a new one until the muro ban duration is lifted. The kapitan duli and kapitan sarilewa, based on the request by the community 
members can offer suggestions for the opening time to the beleng lemo. If the latter agrees, he should call for a meeting with the koten and his deputies. The ritual procession to lift the ban of a muro is similar to the closing ritual.

Yet, this arrangement is more of a reflection of an ideal type than one depicting an actual case. The customary institutions actual work sometimes changed this prescription, as was described in Case 2.

\section{Conflicts of interest}

The authors declare no conflict of interest.

\section{References}

Bakker, K. (2007). The "commons" versus the "commodity": Alter-globalization, anti-privatization and the human right to water in the global south. Antipode, 39(3), 430-455. doi: https://doi.org/10.1111/j.1467-8330.2007.00534.x

Bollier, D. (2014). The Commons as a Template for Transformation. Great Transition Initiative. Retrieved from http://hdl.handle.net/10535/9300

Chikozho, C., \& Mapedza, E. (2017). In search of socio-ecological resilience and adaptive capacity: articulating the governance imperatives for improved canal management on the Barotse floodplain, Zambia. International Journal of the Commons, 11(1), 119-143 doi: http://doi.org/10.18352/ijc.636

Cleaver, F., \& De Koning, J. (2015). Furthering critical institutionalism. International Journal of the Commons, 9(1),1-18. doi: http://doi.org/10.18352/ijc.605

Davidson, J., \& Henley, D. (Eds.). (2007). The revival of tradition in Indonesian politics: The deployment of adat from colonialism to indigenism. Routledge.

Epstein, G. (2017). Local rulemaking, enforcement and compliance in state-owned forest commons. Ecological Economics, 131, 312-321. doi: https://doi.org/10.1016/j.ecolecon.2016.09.012

Euler, J. (2018). Conceptualizing the commons: Moving beyond the goods-based definition by introducing the social practices of commoning as vital determinant. Ecological Economics, 143, 10-16. doi: https://doi.org/10.1016/j.ecolecon.2017.06.020

Griffiths, J. (1986). What is legal pluralism?. The journal of legal pluralism and unofficial law, 18(24), 1-55. doi: https://doi.org/10.1080/07329113.1986.10756387

Gupta, J., \& Bavinck, M. (2014). Towards an elaborated theory of legal pluralism and aquatic resources. Current Opinion in Environmental Sustainability, 11, 86-93. doi: https://doi.org/10.1016/j.cosust.2014.10.007

Harvey, D. (2011). The future of the commons. Radical history review, 2011(109), 101-107. doi: https://doi.org/10.1215/01636545-2010-017

Kahin, Audrey R. (1994). Regionalism and decentralization. in Bourchier, D and Legge J (eds). Democracy in Indonesia: 1950s and 1990s. Monash: Center of Southeast Asian Studies, Monash University. pp. 204-222.

Jones, S. (2015). Bridging political economy analysis and critical institutionalism: an approach to help analyse institutional change for rural water services. International Journal of the Commons, 9(1), 65-86. doi: http://doi.org/10.18352/ijc.520

Miyagana, K and Shimamada, D. (2018). The tragedy of the commons' by underuse: toward a conceptual framework based on ecosystem services and satoyama perspective. International Journal of the Commons 12(1),332-351.doi: http://doi.org/10.18352/ijc.817

Mosse, D. (2006). Collective action, common property, and social capital in South India: An anthropological commentary. Economic Development and Cultural Change, 54(3), 695-724.doi: https://doi.org/10.1086/500034

van der Muur, W., Vel, J., Fisher, M. R., \& Robinson, K. (2019). Changing Indigeneity Politics in 
Indonesia: From Revival to Projects. doi: https://doi.org/10.1080/14442213.2019.1669520

Nugroho, K, Carden, F, and Antlov, H. (2018). Pentingnya Pengetahuan Lokal! Kekuasaan, Konteks, dan Pembuatan Kebijakan di Indonesia. Jakarta: Knowledge Sector Indonesia.

Nyenyezi Bisoka, A. (2019). Competing claims over access to land in Rwanda: legal pluralism, power and subjectivities. Competing claims over access.

Ostrom, E. (1990). Governing the Commons: The Evolution of Institutions for Collective Action. Cambridge: Cambridge University.

Ostrom, E. (2008). The challenge of common-pool resources. Environment: Science Policy for Sustainable Development 50 (4), 8-21.doi: http://doi.org/10.3200/ENVT.50.4.8-21

Ostrom, E. (2010). Beyond market and states: polycentric governance of complex economic system. American Economic Review 100(3), 641-672

Peluso, N.L., Afiff, S., Rachman, N.F. (2012). Membuat alasan dan alas yang sama demi reformasi: gerakan-gerakan agrarian dan lingkungan di Indonesia. Wacana 28, 13-55.

Rachman, N. F. (2017). Petani dan Penguasa: Dinamika Perjalanan Politik Agraria Indonesia. Yogyakarta: INSISTPress.

Sahide, MAK, S Supratman, A Maryudi, Y-S Kim, and L Giessen. (2016). Decentralisation Policy as Recentralisation Strategy: Forest Management Units and Community Forestry in Indonesia. International Forestry Review 18(1), 78-95. doi: https://doi.org/10.1505/146554816818206168

Saragi, T. P. (2004). Mewujudkan Otonomi Masyarakat Desa: Alternatif Pemberdayaan Desa. Jakarta: CV. Cipiruy.

Saunders, F.P. (2014). The promise of common pool resource theory and the reality of commons projects. International Journal of the Commons 8(2), 636-656. doi: http://doi.org/10.18352/ijc.477

Shaw, M. (2014). Learning from The Wealth of the Commons: a review essay. Community Development Journal, 49(suppl_1), i12-i20. doi: https://doi.org/10.1093/cdj/bsu012

Jacqueline, V. E. L., Zakaria, Y., \& Bedner, A. (2017). Law-making as a strategy for change: Indonesia's new Village Law. Asian Journal of Law and Society, 4(2), 447-471. doi: https://doi.org/10.1017/als.2017.21

Wright, E. O. (2011). Commentary: Sociologists and Economists on the Commons. In Pranab Bardhan and Isha Ray (eds). The Contested commons; Conversation between Economists and Anthropologists. Blackwell. 